\title{
THE IMPACT OF BUS TRANS SEMARANG ROUTE TO LAND PRICES AND URBAN LAND SUSTAINABILITY
}

\author{
Anita Ratnasari Rakhmatulloh ${ }^{1 *}$, Muhammad Nur Febrian ${ }^{1}$, Martinus Bambang Susetyarto ${ }^{2}$ \\ and Diah Intan Kusumo Dewi ${ }^{1}$ \\ ${ }^{1}$ Department of Urban and Regional Planning, Faculty of Engineering, Diponegoro University (UNDIP), \\ Semarang, Central Java, Indonesia \\ ${ }^{2}$ Department of Architecture, Faculty of Civil Engineering and Planning, Trisakti University, Jakarta, Indonesia
}

Received 30 August 2020; received in revised form 15 September 2021; accepted 10 October 2021

\begin{abstract}
The phenomenon of urban sprawl is the expansion process of the physical appearance of the city, which generally moved outward to the suburbs through the appearance of the land being built. One of the factors of the expansion is population mobility which closely related the quality of the transportation infrastructure. The growth of urban development is influenced by the transportation system and has increased from time to time. Moreover, urban development is also influenced by the development of public bus transportation routes in Semarang City, Indonesia. The purpose of this research is to find out whether Trans Semarang Bus has an influence on land development in Semarang City. The methods used for this study are spatial analysis, descriptive statistical analysis, and Floor Area Ratio (FAR) analysis. The results showed that the Trans Semarang Bus routes have an impact on the change of the land's physical expansion and land prices along the service route, this is shown in the extensive development along with the road network. Overall, these findings indicate that the Trans Semarang Bus service route influenced the urban physical development due to increased accessibility on this route.
\end{abstract}

Keywords: Urban Sprawl; Land Prices; Accessibility; Trans Semarang; Transportation System; Urban Sustainability.

(C) 2021 Journal of Urban and Environmental Engineering (JUEE). All rights reserved.

\footnotetext{
*Correspondence to: Anita Ratnasari Rakhmatulloh, Tel.: +62821-3304-9555

E-mail: anita.ratnasari.r@gmail.com
} 


\section{INTRODUCTION}

The phenomenon of urban development is closely linked to the process of attraction that is associated with population mobility and ease of movement. The ease of movement (accessibility) for the population is essentially the result of the interaction between land-use and transportation network systems (Drouilles et al., 2018). Several studies on urban development stated that the level of accessibility of transportation tends to trigger population growth in an area. The population growth would increase the intensity of land-use changes, while also increasing land prices as a result of the growing economic activity.

Several factors could influence the increasing land prices. According to research conducted by Swinnen in (Dirgasova et al., 2017), one of the factors that could influence the increasing of land prices is its accessibility. Bus Rapid Transit (BRT) is a form of public transportation that has the ability to increase the accessibility of land (Alterman, 2012). Several studies on the effect of the BRT on land prices had been carried out in several parts of the world. Research conducted by Carvero and Kang (2011) stated that the BRT is able to influence the increasing land prices by $5-10 \%$ when the distance of land is 300 meters away from the bus stop.

The condition of the BRT, which is the object of this research, in some of these countries has had complete components, such as having a special lane. The existence of this special lane affects the speed performance of the Bus, enabling it to avoid traffic. This is different from Trans Semarang, which is one of the Bus Rapid Transit (BRT) development models in Indonesia. Trans Semarang does not yet have complete components such as special lanes. Consequently, the performance of the speed provided is still not optimal. This could be seen during peak hours, where the Trans Semarang would be stuck in traffic along with other personal vehicles. As a result, the community's interest in using the Trans Semarang is still low.

The low of community's interest could be seen by the value of the passenger load factor of all corridors that is still below the standard, which is $70 \%$ minimum. However, in the span of a few years since the inauguration of Trans Semarang, the number of passengers has increased. According to data from previous research, it was found that the number of Trans Semarang passengers in 2009 was 369.326 people and then experienced a significant increase in 2018 to be 9.125.472 passengers. This is due to the addition of new corridors from year to year. The high movement indicates that the land in this corridor has high accessibility. Responding to this, a provisional hypothesis was raised, which stated the increase of land prices and accessibility in the surrounding area was due to the existence of the Trans Semarang.

In addition, the high rate of accessibility due to the existence of Trans Semarang is indicated to accelerate the urban development which it traverses. These areas would experience the development of built-up land. Based on research on the Development of the Japan Transit Hub (Yang and Yao, 2019), optimizing passenger traffic flow of transportation could improve the allocation of land resource use as well as the quality of space for socioeconomic needs. Therefore, the purpose of this study is to determine the effect of the Trans Semarang's accessibility on land prices, and their influence on the urban sprawl phenomenon in relation to land-use allocation. This indicates to have experienced a breakdown following the development of transport providers.

Infrastructure is an important tool used to increase the investment, expanding the reach of community participation, and equitable distribution of development results in remote areas. Baldwin and Dixon in (Palei, 2015) study of economic theory explained that infrastructure could drive the economy and support the national defense and security. Infrastructure is also an important influence for improving the quality of life and welfare of the community through easy access to various needs of life. One of the important infrastructures that are the basis for driving economic activity is the provision of transportation to create the ease of movement (accessibility) of people and goods. The quality and type of infrastructures required by an area are strongly influenced by the natural characteristics and distribution patterns of the population that is unique in the area (Palei, 2015).

So far, macro views in various parts of the world have concluded that the existence of infrastructure and ease of accessibility has a very positive impact on housing prices. Based on a study conducted by Liu, Min, Zhao and $\mathrm{Hu}$ (2020), stated that the impact of public transportation infrastructure on housing prices depends on the type of transportation system available. Fast transportation connected to suburban areas such as subways and trams are considered to have a more positive impact on land use changes and housing prices, compared to other modes of transportation.

According to Black and Conroy (1977), accessibility is a concept that combines a geographical land-use regulation system with a transportation network system that connects them. Accessibility is a method used to measure the level of comfort or ease of movement regarding interactions between land-use locations through a transportation network system. Fundamentally, accessibility is the easiness of reach for people and goods to move from one activity's location to another.

The value of access to land is obtained from its ability to reach places that have been determined by land-use patterns, as well as the availability of transportation networks. Without transportation networks, the land would not have access, meaning that it would only be valued from natural resources. It could also mean that the structure of the building above it 


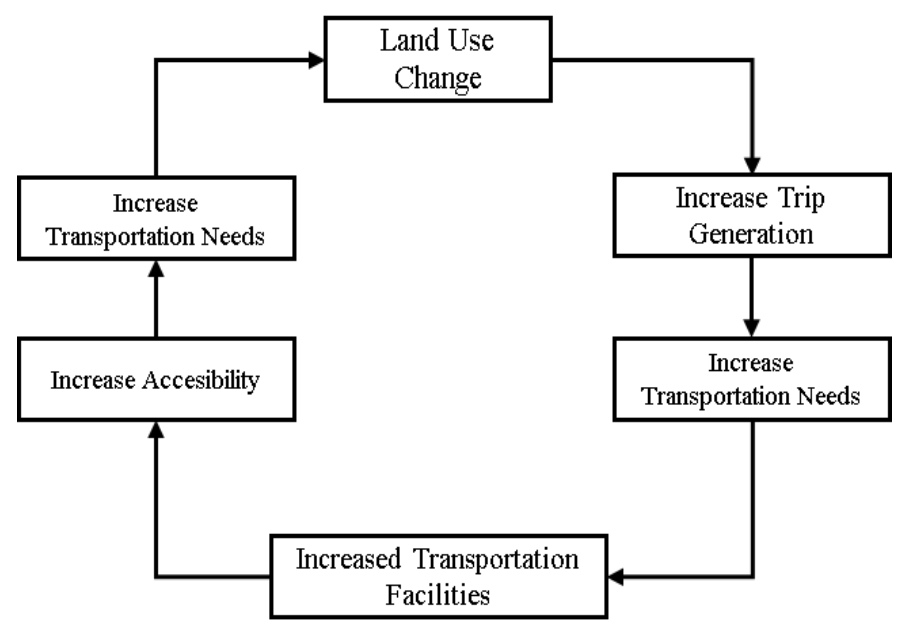

Fig. 1. The cycle of transportation needs

has no value. Accessibility is a factor that causes the interaction between land and could provide an opportunity economically, which in turn could change the value of land (Levinson and Istrate, 2012).

The level of accessibility could be measured using distance, time, and travel costs. A piece of land could be considered to have good accessibility if the distance is close to the others, the travel time to reach a desired location is relatively fast and the cost one must spend to reach the desired location is relatively low. This statement is in line with the research that's already conducted (Rakhmatulloh et al., 2018), which stated that accessibility could be seen or measured by looking at the distance, travel time, and travel costs and would have an impact on production and sales. Accessibility is one of the keys to the transportation policy. Investments made by the government in the provision of public transportation would increase accessibility to locations where users or the public could directly be served by these investments (Jain et al., 2014). Principally, the increased accessibility is caused by the existence of public transportation facilities, which in turn could affect the price of land and land use changes due to an increase in the intensity of investment activities as shown by Fig. 1.

According to (Rodriguez and Targa, 2004), over the last few years, various countries have carried out research to determine the characteristics of more desired modes of public transportation. For example, the investment costs required by the BRT are relatively low compared to other modes of public transit transportation such as trains and metros. In addition, the implementation of BRT is flexible and can be done in stages. Nonetheless, research on the influence of the BRT on land value is still very limited. Alonso in (Mulley and Tsai, 2016) explained that land rent or land value increases as accessibility increases. This can be achieved with the implementation of new transportation that is able to provide good accessibility. The BRT is a public transportation mode that has high accessibility capabilities (Alterman, 2012).

Changes in land value due to stimulation from the existence of BRT is an effect or impact that could be seen directly, while the long-term impact is the changes of land-use. This happens because the increased land value would be able to provide optimal use in land parcels so that in the end it would provide an impetus for changes in land-use (Mulley and Tsai, 2016). However, the impacts of the addition of transportation could alter the value of land surrounding it as a result of increased accessibility to the area. This would affect the price of the land, where the closer a piece of land is to a BRT stop, the higher land price would be.

Several studies have been conducted related to the influence of the BRT on land price; this has been done in various countries such as the Bogota Transmilenio Colombia BRT, Brisbane Australia BRT, Beijing China BRT, and Seoul Korea BRT. According to the research of Rodríguez and Targa (2004), the BRT of Bogota can give effect to the increase in land price: when the required travel time is between 5-10 minutes, the land price would increase by $6.8 \%-9.3 \%$, whereas if the travel time is more than 10 minutes, the influence exerted would drop to $2.8 \%$.

Similar research conducted regarding the Seoul Korea BRT by Carvero and Kang (2011) stated that the influence it exerted on the value of land for occupancy increased by $5-10 \%$ from the distance of 300 meters. However, non-residential / retail land values increased by more than $25 \%$. Both studies are in line with research conducted by Mulley and Tsai (2016) on BRT Brisbane Australia, which explained that the residential property located every 100 meters closer to the BRT station offered prices which increased by $0.13 \%$. This is equivalent to $\$$ AUD749. In addition, the BRT could be an additional income for local governments through land value capture or land tax from rising land prices.

Based on the description above, it can be concluded that the accessibility of land increases when traversed by the BRT, thus increasing the land's value. This means that the closer the piece of land to a BRT stop leads to the higher the level of accessibility, therefore increasing land prices. The effect that the BRT has on land prices could be used as an alternative for local governments to increase financial income by capturing land values or taxes from the high land prices. Furthermore, the increase in tax revenue could be used by local governments to provide quality improvements in infrastructure, thus enabling advancement in the region.

At present, most of the urban growth practices consist of two main things: the renewal or regeneration of the built area in the interconnected city center, and predicting the possibility of new developments in the suburbs due to the urban process (Drouilles, 2018). Urban development occurrences are closely related to 
the process of population movement, which in this case is related to the strength of transportation procurement as a means of movement. For example, urban development that is strongly influenced by the Hub Transportation system has increased over time.

The development of the city which initially focused on urban centers such as Tokyo, Nagoya, and Osaka, experienced growth towards the suburbs due to population surges caused by tourism activities. As a result, the government decided to increase the capacity and reach of the transportation network through the Hub Transportation System. Since then, there have been changes in land-use and an increased provision of supporting facilities in rural areas. The urban regeneration process carried out by Japan is a manifestation model of a compact city by optimizing the function of buildings and the integration of transportation to create urban sustainability. The phenomenon of urban sprawl is the process of expanding the physical appearance of the city, which generally appears to move towards the outside (suburban areas) through the appearance of built land. This phenomenon is usually characterized by urban areas that are growing faster than the population, causing the density of land built in the city center to decrease (Mustafa and Teller, 2020).

This expanding process generally occurs in suburban areas that are still largely dominated by agricultural land and vacant land with minimal buildings, commonly referred to as urban fringe. According to Galster et al (2001), urban sprawl is a land development pattern that includes 8 dimensions: population density; development within the reach of the road network; the concentration of building density; the grouping of buildings; centralization; mixed land-use; distance to the city center and closeness of was conducted to different landuses. In addition, based on the results of research conducted (Glaster et al., 2001) increased accessibility could lead to an urban sprawl ribbon development type, which is the expansion of urban development towards the periphery, caused by the accessibility factors with easy access to roads.

In addition to this land conversion, land conversion functions that threaten food availability and could also threaten public health and environmental degradation through carbon emissions (Ewing et al., 2002). This is certainly very contradicts to the economic theory of development explained by Rostow in Hunter (2012), which stated that ease of accessibility through transportation could improve the quality of life and welfare of the community. This condition is also supported by research on the influence of urban sprawl in South Korea, which showed that economic factors such as employment could affect the formation of the process of urban expansion from the city center to the periphery, especially in morphological aspects (Hwang and Woo, 2020).
Based on research conducted by Lityński and Hołuj (2020) there are three methods used to see the level of influence of urban sprawl, namely by looking at the development of built land (settlements), migration processes, and the implementation of spatial policies in an area. Besides, the policy of FAR (Floor Area Ratio), business permit, and residence permit could be used to take measurements of the level of urban sprawl and its intensity in varying areas. These could be done by looking at the total area or number of building floors in an area indicated by an intensive land-use change (Yang and Yao, 2019). In this case, an analysis of land changes would be conducted in corridor 1 of the Trans Semarang. As one of the mass transportation type in the city of Semarang with the goal of creating a sustainable mode of transportation for the community, it would certainly be important to see how the influence of the existence of the Trans Semarang changes in urban planning. This is because the urban sprawl phenomena could cause the city services functions are inadequate, which may mean that urban facilities are not available effectively and efficiently.

\section{STUDY AREA}

The focus of this research object is the influence of the existence of Trans Semarang shelter corridor one, changes in land use, and the increase of built land that is used as analytical infrastructure. The discussion in this study will be divided into two parts, namely the Simpang Lima - Penggaron area and the Simpang Lima - Mangkang region. Retrieval of data points for the Trans Semarang shelter point and land being sold using field observation techniques. Then to find out the price of a square meter per square meter the data collection technique was carried out by interviewing the landowner.

The scope of the study area in this study is 1000 meters from the land directly facing corridor one (Fig. 2). The study area for the Penggaron section covers 5 districts including Pedurungan District, Gayamsari District, East Semarang District, South Semarang District, and Central Semarang Kecamaan. While the study area for the Mangkang section covers 6 districts including Central Semarang District, South Semarang District, West Semarang District, North Semarang District, Ngaliyan District, and Tugu District. Each of these subdistricts has different functions under the BWK or City Area Division Plan.

\section{METHODOLOGY}

The method used in this study uses a quantitative approach with spatial analysis techniques, descriptive statistical analysis, and Floor Area Ratio (FAR) analysis. Descriptive analysis is used to analyze land use in the region around corridor one, land prices, and the effect of accessibility with the phenomenon of urban 


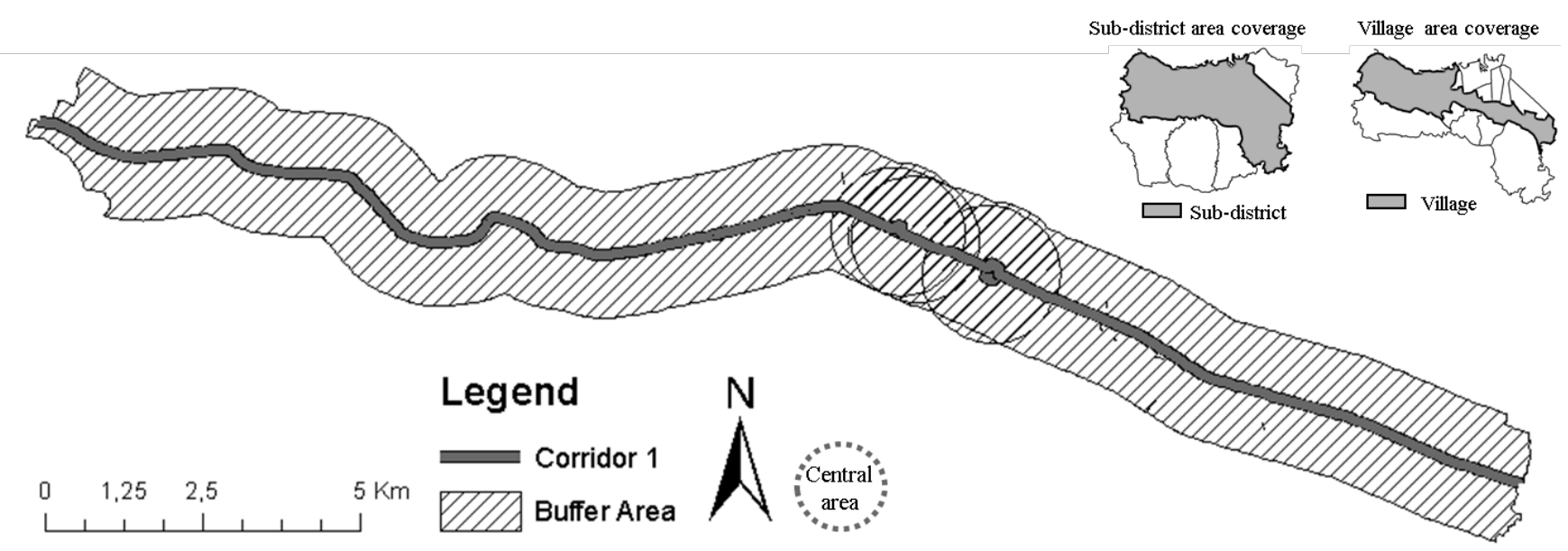

Fig. 2. Study area (buffer 1000 meters)

sprawl. Spatial analysis is used to see changes in land use and the increase of land built along corridor 1 . While the FAR analysis, is used to see the process of rolling using the height and number of building floors.

Spatial analysis is an analytical model that uses Geographical Analysis Systems to interpret data. The query and overlay system is one of the easiest tools to use in the spatial analysis process. The spatial analysis method allows researchers not to search for data directly and rely more on earth's surface image data. Spatial analysis is used to solve spatial problems effectively and efficiently. Land use, built-up area, population, number of bus stops, land price, and distance from the city center are processed using the ArcGIS 10.3 application to produce output in the form of maps and other spatial features. The presentation of data based on actual conditions on the ground is needed to carry out an accurate process of changing land patterns. Delineation of residential buildings on each side of the road network using a spatial query process following the boundaries of the study area.

Descriptive statistical analysis is the simplest type of analysis used to process data into certain information in the form of simple mathematical calculations, graphs, diagrams, and tables. Sprawl level analysis is included in the numerical descriptive analysis which in the analysis process utilizes spatial data in the form of changes in usage within a radius of 1000 meters from the road network. This analysis is an analytical method whose function is to determine the level of spread (sprawl) of an area more accurately based on formulas. This analysis is used to strengthen the results of the interpretation of the previous spatial analysis in terms of the identification of urban slag. Besides, the data point of distribution of land prices that have been collected using the primary data collection process based on the latest conditions is processed in the form of a Scatter plot diagram.

Floor Area Ratio (FAR) is used by countries in the world, one of which is Japan in seeing the effect of the development of new transportation on the effectiveness of land use allocation in its path. FAR is a direct determining standard for the process of land change that occurs. Relevant to the current condition of the building at the study site, the average FAR sampling per building is based on the average characteristics that represent each region. The number of floors or the height of the building represents a model of development of built land which tends to be vertical or horizontal.

\section{RESULT AND DISCUSSION}

The city of Semarang began developing the BRT transportation route in 2009 , at the time there were 7 corridors. This then increased to a total of 12 corridors. The development of the new transportation system affected the population growth which was initially quite high, especially in areas with adequate access to the BRT stops. This caused a lot of changes in land-use from the center of Semarang to its the suburban areas. Based on this research results, Corridor 1 Trans Semarang itself was the first corridor that was built in Semarang City which started a total of 369.326 passengers. However, this number then experienced a significant rise to 3.408 .650 people in 2017 , which in turn dramatically increased the accessibility and mobility of the community from the city center to the periphery. Moreover, this also caused the conversion of agricultural land to built-up land.

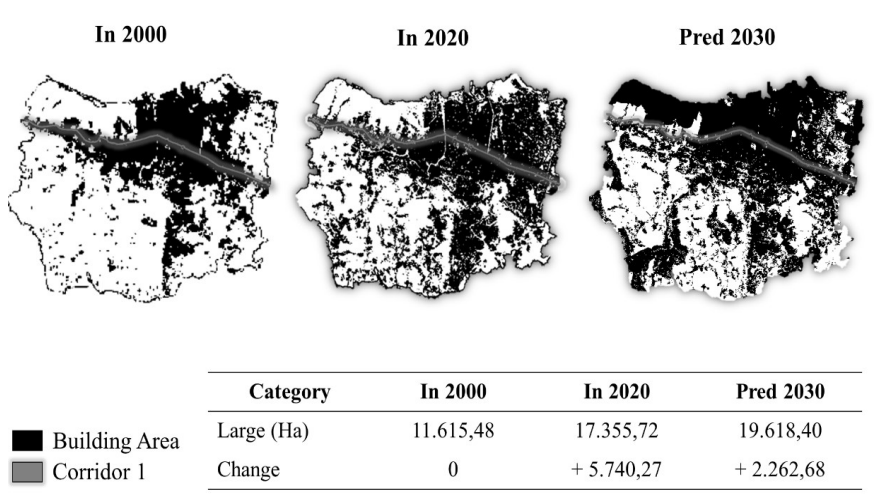

Fig. 3. Comparison of land built in the City of Semarang: comparison based on imagery and tabulation of increments per ten years. 
Land-use in the city of Semarang itself from year to year is increasingly experiencing the existence of builtup land. This is evidenced by the increasing intensity of construction, specifically in parts of the region close to the city center. Based on this research, the land used for development in the city of Semarang is predicted to continue to increase due to the high intensity of land-use change, especially in the areas leading to Demak Regency. Fig. 3 illustrates the development in land use as a settlement from 2000 until the present year 2020, and predicts this trend would continue to increase until 2030, where the trade and services industry would expand to the southern part of the city. Relatively wide land changes still occur mainly in areas along corridor 1, from Mangkang to the Penggaron area. In this case, there are two parts of the region that are centered at Simpang Lima, namely the Simpang Lima - Penggaron section, and Simpang Lima - Mangkang.

Based on the data obtained in this study, there are 16 types of land-use in the Penggaron area. Nonetheless, two types of land use dominate the area: trade and services, with 389.1 hectares, and settlements with 984 hectares. Built up area made up of $93 \%$ of the Penggaron area, while the remaining $7 \%$ of the land has not yet been developed. In contrast, there are 18 types of land-use in the Mangkang area, three types of which dominate the area. The three types of land-use are including trade and services, with an area of 457 hectares; settlements, covering an area of 1.204 hectares; and industries, covering an area of 635.5 hectares. In addition, the area of land that has not yet been developed made up of $21 \%$ of Mangkang, contrasting the $79 \%$ that has been developed.

Based on the land use description Fig. 4 graphically and Fig. 4 spatially shows that the two parts of the area (Simpang Lima - Penggaron and Simpang Lima Mangkang) have some similarities and differences in characteristics. The equation of the two is the dominance of land-use that functions as a settlement as well as trade and service. This type of land-use is a land-use that functions as a settlement and trade and services are land that could provide a pull or a large trip generation because, in theory, the development of economic activity is accelerating the process of urban sprawl (Mamcarczyk et al., 2020). This shows that the land in this corridor is the center of Semarang City's community activities, that of which has high accessibility. The high accessibility could influence the land prices as stated by Cervero and Kang (2011).

The difference between the two areas is that besides functioning as a center for settlement as well as trade and services, the Simpang Lima - Mangkang area also functions as an industrial center for Semarang City. In addition, the undeveloped land is larger here than in the Simpang Lima - Penggaron region, making up 21\% of the area, contrasting the $7 \%$ in the Penggaron area.

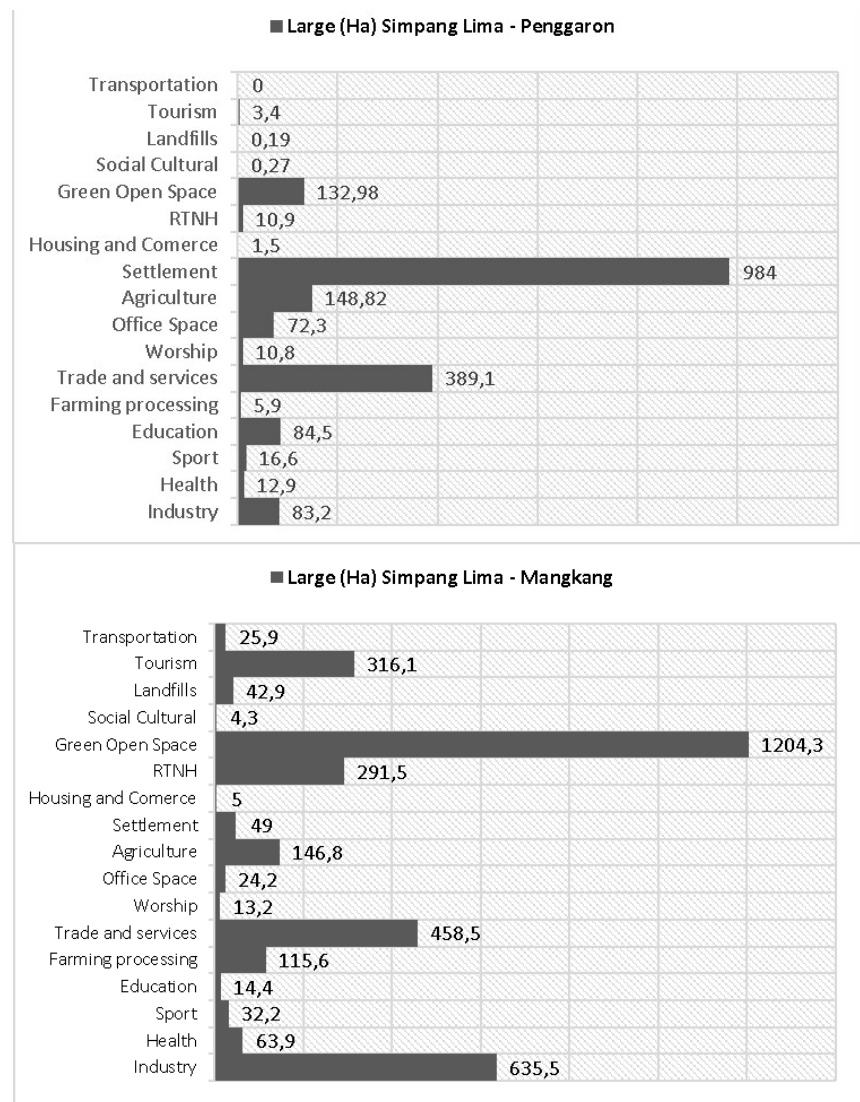

Fig. 4 Intensity chart of corridor 1 land use : area per hectare of Simpang Lima - Penggaron and Simpang Lima - Mangkang sections.

These statistics suggest that the level of population density in the Simpang Lima - Mangkang area is lower than the level of population density in the Simpang Lima - Penggaron area. This could give an effect on the difference in land prices of the two. According to (Dirgasova et al., 2017), high population density influence land prices because there is a correlation between the number of wage levels, income levels, and people's purchasing power which could certainly affect the demand and supply for goods or services that is in demand and supply for land.

Based on the spatial change map Fig. 5, land-use in the corridor 1 area experienced many changes from 2000 to 2020. Based on the results of land use data in this study it was found that there is a tendency to expand between the two parts of the Simpang Lima Penggaron and Simpang Lima - Mangkang with a large level of expansion towards the Penggaron which is much higher at $61 \%$ when compared to the distribution tendency towards the Mangkang only $32 \%$. If viewed based on the overall expand calculation (sprawl), the level of land-use changes and expansion is $48 \%$ which is included in the medium category. It is also in line with the increasing accessibility and value of land in the corridor 1. Calculations were made using data from land built in 2000 as a base year and land built in 2020 as a comparison. Measurement of sprawl level based on the results of the scoring there are 3 typologies of 


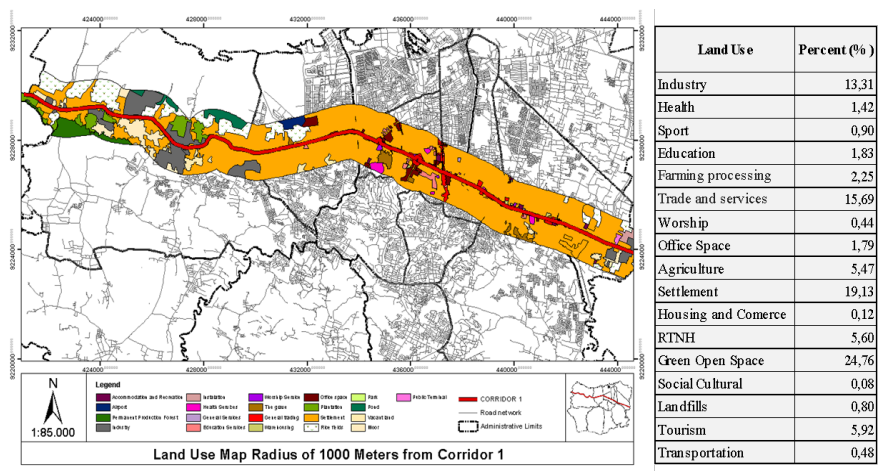

Fig. 5 Land-use corridor 1 (Mangkang - Penggaron) : total land use accumulation of corridor 1 in percent.

development change, namely typology $1=$ low $(\leq 35 \%)$, typology $2=$ moderate $(36 \%-58 \%)$, and typology $3=$ low $(\geq 59 \%)$.

Sprawl (\%) $=($ land developed P1 - land developed Po $)$ / land developed Po x 100

\section{Information:}

$\mathrm{P} 1=$ End year $(2020)$

$\mathrm{Po}=$ Initial year $(2000)$

\section{Simpang Lima - Penggaron}

Sprawl $(\%)=(2.290,955 \mathrm{Ha}-1.415,108 \mathrm{Ha})$ $1.415,108 \mathrm{Ha} \times 100=61 \%$ (High)

\section{Simpang Lima - Mangkang}

Sprawl $(\%)=(1.527,303 \mathrm{Ha}-1.157,816 \mathrm{Ha})$

$1.157,816$ Ha x $100=32 \%$ (Low)

\section{Penggaron - Mangkang}

Sprawl $(\%)=(3818,258 \mathrm{Ha}-2572,924 \mathrm{Ha}) /$

2572,924 Ha x $100=48 \%$ (Medium)

Based on the results of data collection on land prices, it was found that the Penggaron section has different land prices according to the location of the land. The area of the Penggaron has different land prices according to the location of the land. The highest land price is IDR 48.006 .756 while the lowest land price of IDR 4.968.944. Whereas the Mangkang section has the highest bid price of IDR 32.000.000 and the lowest bid price is IDR 2.117.143. Based on these data it can be seen that the two regions have considerable differences in land prices. This is a that the economic level of the Penggaron region is higher than that of the Mangkang region.

Based on Fig. 6 above, it is clear that the two regions have similarities in their land price patterns. The graph indicates that the pattern of land prices is not linear or monocentric, as stated by Von Thunen, but is multicentric as explained by McCann (2001). A multicentric pattern is a pattern of land prices in which the farther the distance of land from the city center, the lower its price would be. However, there are several points of land that have had an increase in price due to the sub-centers of activity in those areas, inevitably resulting in land prices that are increasingly rising.

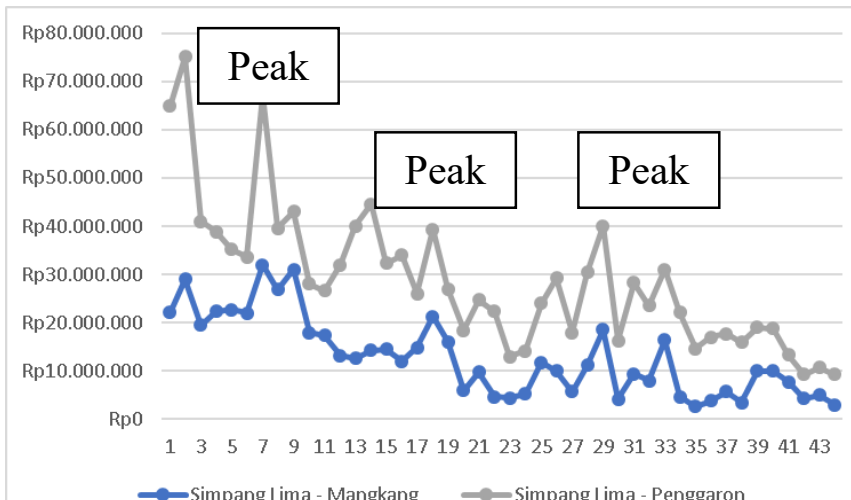

Fig. 6 Land prices along the corridor 1 : from the city center to the suburbs.

Based on the results of the data carried out in this study, it is obtained the form of a chart of land price patterns for the Penggaron region (Fig. 5), there are 3 areas that have increased land prices. The first area is in around Majapahit street, where there are modern market uses such as Lottemart, health facilities such as Bhayangkara Hospital, and educational facilities, namely SMPN 2 Semarang City. The second area is around Majapahit road; the use of the land is near the Bhayangkara Hospital health facility. In addition, in front of the piece of land, there is a bus stop that provides convenience for mobility. The third peak area is around Brigadier Sudarto street. The surrounding land-uses are Semarang City Samsat office facilities, a Transmigration and Disability Training Center, and Gondhohutomo Hospital health facilities.

Furthermore, the land price chart patterns for the Mangkang area shows that there are 3 areas that have increased land prices (Fig. 5). The first peak area is around Jalan Imam Bonjol with the land used as a center for trade and services area such as Paragon Mall and DP Mall, Education area such as UDINUS \& SMA 3 Semarang City, and Offices such as the Semarang City Bappeda office etc. The second peak area is around Jalan Jendral Sudirman, where the use of the surrounding land functions as trade and services area such as Karang Ayu Market and Giant Siliwangai, Education area such as SMAN 6 Kota Semarang and SMPN 1 Kota Semarang, and Settlement. The third peak area is on Walisongo road, with its land-use functions as Education area such as UIN Walisongo, and Offices area such as the PLN Office, and BP2MHP.

The data obtained is based on the identification of the overall land price; distance to the city center; and the number of BRT stops available along corridor 1 . Clustering is based on the distance from the city center as seen by Table 1 . As shown on the available public table, it can be seen that there is a correlation between the accessibility seen from the distance from the city center and the number of bus stops available with the price of land in corridor 1 .

The tabulation of data is based on the method of class formation that stems from the closest and farthest 
distanced land from the city center. Class 1 is the nearest area with a distance of $0-62 \mathrm{Km}$, class 2 is an area with a moderate distance covering of $63-125 \mathrm{Km}$, and class 3 has the farthest distance covering of 126 $188 \mathrm{Km}$. The division of classes uses the formula of determining the interval from the highest data minus the lowest data, where there is an influence of the distance caused by the amount of halted and land prices. The farther the distance from the city center, the less the number of BRT provided, and the price of land offered also tends to be cheaper.

In addition to the number of bus stops, in determining the land accessibility this study used a comparison method (tabulation) which was done by comparing land access data or locations reaching the bus stops. The identification of the travel distance used to measure the level of accessibility in this study utilizes travel time from the location point to the Trans Semarang stop facility. It was based on the results of research presented by Augustus (2012) stated that to measure the level of accessibility could be measured using travel time.

The scatter graph in Fig. 6 shows that the relationship between the land travel time and bus stops in the Penggaron area has a negative pattern. This pattern means that the faster the land travel time for the Trans Semarang, the higher it is for the land prices, while the longer the travel time required to reach a bus stop, the land prices would decrease. The longest travel time from one area of land to the Trans Semarang BRT stop is 7 minutes, which is still under 10 minutes.

The results from data collection on land prices along corridor 1 also produce scatter plot graph figure section of Simpang Lima - Mangkang which shows that the relationship between land travel time to the Trans Semarang shelter has a negative pattern. This pattern indicates that the faster the land travel time for the Trans Semarang, the higher the land prices, and conversely, the longer the land travel time needed to get to the bus stop, the lower the land prices. However, the travel time needed to get from the point of land to the Trans Semarang stop exceeds 10 minutes, at 12 minutes. This is in line with research conducted by Rodríguez and Targa in(Deng, Ma, and Nelson, 2016), which stated that any land that has a 5-10 minute walk to the BRT Bus Stop could have an influence on land prices of 6.8$9.3 \%$.

Table 1. Relationship between city center distance, number of bus stops and land prices.

\begin{tabular}{cccc}
\hline Typology & $\begin{array}{c}\text { Distance } \\
\text { Range } \\
(\mathbf{K m})\end{array}$ & $\begin{array}{c}\text { Number of } \\
\text { Stops } \\
\text { (Unit) }\end{array}$ & $\begin{array}{c}\text { Land Prices } \\
\text { (Million Rupiah) }\end{array}$ \\
\hline 1 & $0-62$ & 154 & 19 \\
2 & $63-125$ & 84 & 11 \\
3 & $126-188$ & 55 & 5 \\
\hline
\end{tabular}

*Notes: Formation of 3 classes using the interval formula by doing the highest value with the lowest value to get a long interval.
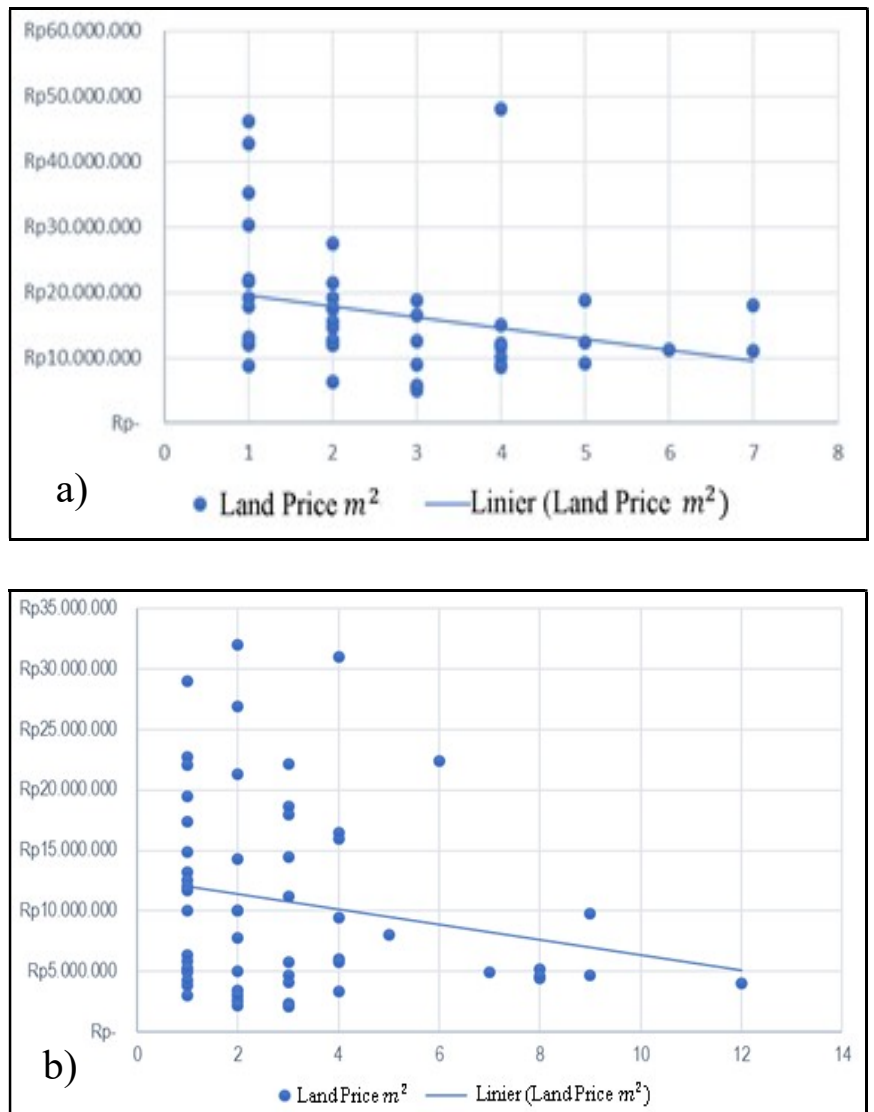

Fig. 7. Scatter plot graph of the relationship between bus stop time and land price in the Penggaron section: (a) Simpang Lima Penggaron, (b) Simpang Lima - Mangkang.

Based on the results of the tabulation comparison and scatter plot graph, it can be seen that there are effects that arise from the ease of accessibility of the price of land. The first effect is the distance of the land to the Trans Semarang stop at an average travel time of 1-7 minutes. This is in line with research conducted by Rodríguez and Targa in (Deng, Ma, and Nelson, 2016) which stated that land rental prices would increase by about $6.8-9.3 \%$ for every 5-10 minute walk. Nevertheless, according to (Munoz-Raskin, 2010), the price of land would increase by at least 5\% with a 5-10 minute travel time. This means that the Trans Semarang could provide an increase in accessibility or convenience for the community to make a move, especially land located along corridor 1 . This high accessibility could influence an increase in land prices. This is consistent with research from (Alterman, 2012) as well as the theory put forward by J. Paquette in (Rakhmatulloh et al., 2018), which stated that the BRT could provide increased accessibility, which would have an influence on increasing land values and land prices.

The findings of this study are in accordance with research conducted by Bocarejo, Portilla, and Pérez (2013) which stated that the BRT system is able to exert an increase in the value of the land on land-uses that function as trade and services. In addition, according to (2011), the value of land for residential use or settlement increases in value by $5-10 \%$ with a distance of 300 meters from the bus stop. However, for non- 
residential uses or retail, it increases by $25 \%$. Therefore, it is clear that land-use around the BRT stops play an important role in its influence on land prices.

Nonetheless, based on the T-test or partial differences in the effect of the existence of the Trans Semarang BRT shelter on the two parts of the region, namely for the Mangkang area, the presence of the Trans Semarang has not had an effect on land prices (or the effect exerted is smaller than the Penggaron section). However, for the Penggaron area, the existence of the Trans Semarang could have a significant influence on land prices. After a more in-depth analysis, it was found that this is due to the two area having two different characteristics. The difference related to the land-use characteristics that have been described previously, which then affect the level of population density between Penggaron and Mangkang. This causes a difference in land value, wherein the Penggaron region has the lowest land value of $\mathrm{Rp}$. 4.9 Million, while Mangkang has the lowest land value of up to Rp. 2.1 Million per square meter.

Consistent with research conducted by Huang in (Dirgasova et al., 2017), which stated that the level of population density has a correlation with the level of wages, the level of income and community purchases means that the higher the level of population density, the higher the level of public demand for goods or services. Conversely, the lower the level of population density of an area, the lower the level of demand and supply for goods and services. There is an area where the travel time to a bus stop could reach 12 minutes, exceeding 10 minutes. If examined in more depth, this is in line with research conducted by Rodríguez \& Targa which stated that the travel time of an area above 10 minutes to the stop only increases land prices by $2.8 \%$, whereas land that takes 5-10 minutes to stop increases by $6.8 \%-9.3 \%$.

Moreover, this is also in line with research from (Munoz-Raskin, 2010), which stated that the increase in land value of areas close to BRT impacts those with middle and upper incomes (meaning that when viewed economically, the area of Penggaron and Mangkang have differences in community incomes).

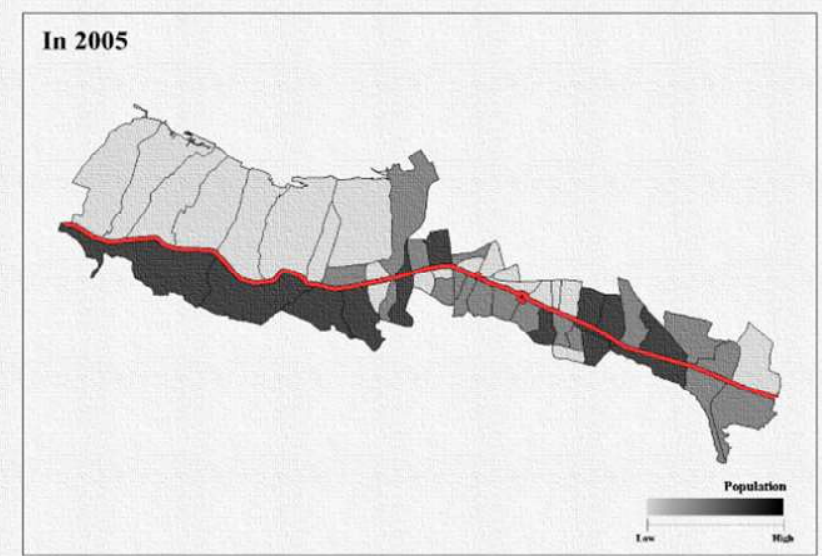

This suggests that the average income of those in Penggaron is higher than that of those who live in Mangkang. Furthermore, in the Penggaron area, the furthest distance from the land to the Trans Semarang stop has a travel time of 7 minutes, which is evidently less than 10 minutes. This is in accordance with research conducted by Rodríguez and Targa (2004) BRT, which stated that the BRT could influence the land price of $6.8 \%-9.3 \%$ with a range of time between 5-10 minutes to the bus stop. However, if the travel time from the land point to the BRT bus stop surmounts 10 minutes, the effect given to an increase in land prices would decrease.

The construction of the Trans Semarang Corridor I BRT began in 2009, which served trips from the Mangkang Terminal to the Penggaron Terminal with the highest number of accessing stops available among all corridors (Rakhmatulloh et al., 2018). The identification of land prices in the presence of the BRT shows that one of the main factors causing the high price of land along corridor I was the ease of access from the land to the BRT stop. Based on the appearance of the land that was built from 2000 (before the existence of corridor 1) to 2020 (after the existence of corridor 1), it could be seen that the change of built land was very rapid, especially in areas near the center of Semarang City.

The conversion of land to built land spreads (sprawl) from the center to the periphery occurs due to the development of infrastructure and economic activities (need and stress theory). The effect of accessibility on land prices in Mangkang to Penggaron also has implications for building construction motives. Land prices are becoming increasingly expensive in central areas that are connected by mass transportation such as the BRT, causing many people to choose to build housing in the outskirts of the city due to its relatively cheap land prices. This is relevant to previous research in (Rakhmatulloh et al, 2018), which stated that corridor 1 has the densest stop point, while corridor 4 has a relatively rare stop point. Upon further inspection, this is of course further linked to the phenomenon of landuse change that is relatively dense in areas with the most stops of transportation services, including which have

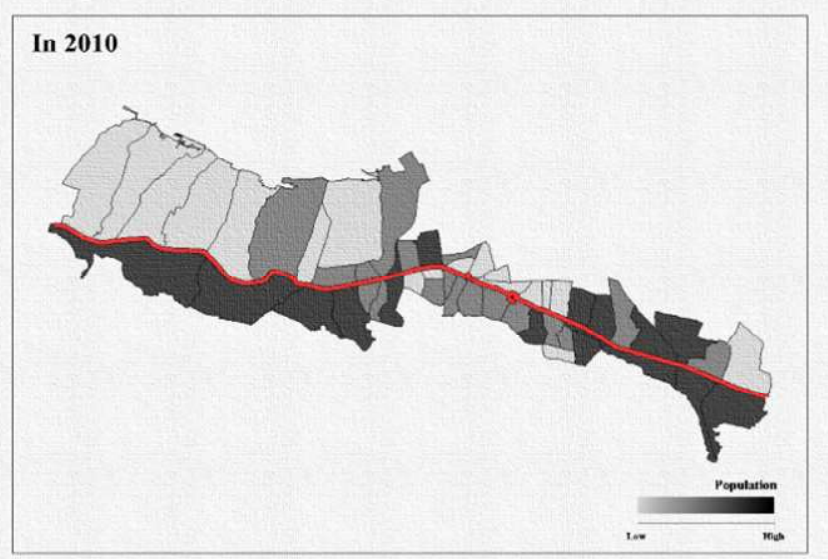

Fig. 8 Changes in population concentration along corridor 1: using data on the number of residents per village. 
continuing travel connectivity facilities.

Based on the study of urban sprawl in the outskirts of South Korea (Hwang and Woo, 2020), stated that one of the factors that encourage urban spreading is the spread of population from the city center to the suburbs. This also occurs in the 1000 meter radius area of corridor 1 of BRT Trans Semarang, which covers 50 villages from 8 sub-districts, where the results of data processing in this study indicate that it occurs there is a change in the direction of the outskirts of the city, the majority of which head toward the Penggaron marked with a solid color (relatively large population) on the map. which is increasing. Within 5 years before (in 2000) and after the existence of the Trans Semarang corridor 1 (in 2010), there has been a shift in population movements from the city center to the suburbs, one of which is influenced by the ease of accessibility as shown by Fig. 8 .

The sprawl rate calculation is based on research conducted to test the intensity of land-use in the area traversed by the rail hub in Japan. The FAR value indicates a high level of land-use optimization (Yang and Yao, 2019). This supports the City Compact theory that optimizes vertical land growth accompanied by an optimal increase in mass transportation services. The expand of the distribution analysis would be carried out using the area segmentation method consisting of segment 1 suburbs and segment 2 downtown areas. Segment 1 consists of the Mangkang and Penggaron area, while Segment 2 is the central area of Semarang City. Perhaps, in reality this distribution analysis must be rechecked with the number of residents living, and working residents boarding in the city, or who commute round-trip every day.

Fig. 9 shows that the building envelope is divided into two segments. It also shows that the majority FAR of buildings in the center of the city (segment 2) have a more optimal land-use allocation pattern compared to the periphery (segment 1). The highest number of building floors in this area is 10 floors with a height reaching 40 meters. The building, which is mostly used as a commercial destination, has a mixed function as a residential, office, shopping center, and also a vehicle parking lot. Based on research conducted by Yang and Yao (2019) on transportation hubs in Japan, the growth of buildings in the vertical direction with a mixedfunction intends to create a pattern of compact and optimal urban development, thus minimizing irregular city traffic. Relative to segment 1, Mangkang and Penggaron are areas with a building envelope appearance, the majority of which have FAR of 1 to 2 floors. Its location is increasingly spread away from the city center. This building envelope condition is indicated to be a less optimal land-use pattern because it is predicted to have many land conversions to the horizontal following the development of roads and transportation.

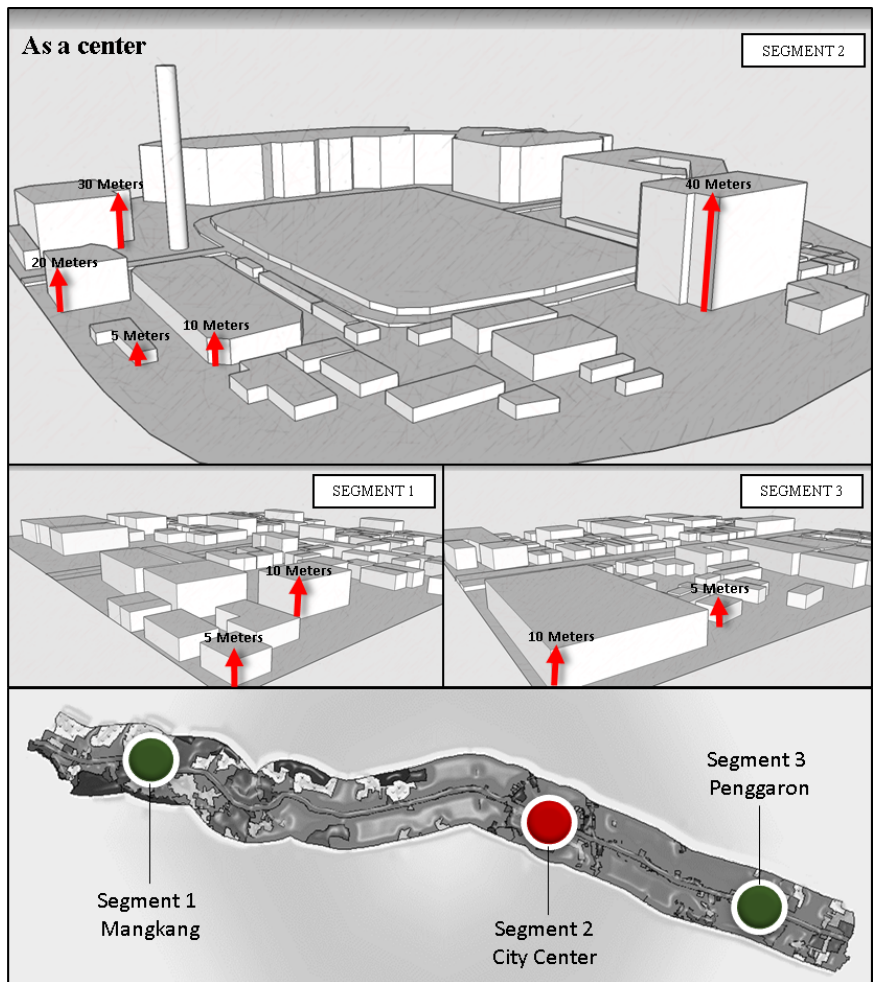

Fig. 9. Appearance floor area ratio (FAR) per segment: sampling based on certain points in all three sections.

Based on the cross-section results in Fig. 10, the appearance of the building from the city center to Mangkang and the city center to Penggaron shows that there is a pattern of sludge affected by the activity and also the function of the land around the area. The Mangkang area (segment 1), which is dominated by industrial land-use, has a FAR, which is majorly 1storey buildings for settlements, and 2-storey buildings (equivalent) for trade, services, and industry. The expansion of land development is very visible in the Mangkang segment because there is still green land that separates buildings. This is also influenced by the impact of very massive industrial activities in the Kendal Regency.

Additionally, in segment 2, it is evident that the downtown area has fairly dense built-up land criteria; it includes a building that is more compact and has a FAR of more than 2 floors, while the majority of land-use is for trade and services. The Penggaron area (segment 3 ) has a fairly dense distribution pattern compared to the Mangkang Segment, where the majority of FAR consists of 1 floor, and land-use is dominated by residential areas. The research becomes very comprehensive if real calculations are made of the people living in the built zone, and the people commuting who fill the Penggaron segment and the Mangkang segment in daily activity. Likewise, the calculation of the flow density of incoming and outgoing goods is carefully calculated in both segments. 


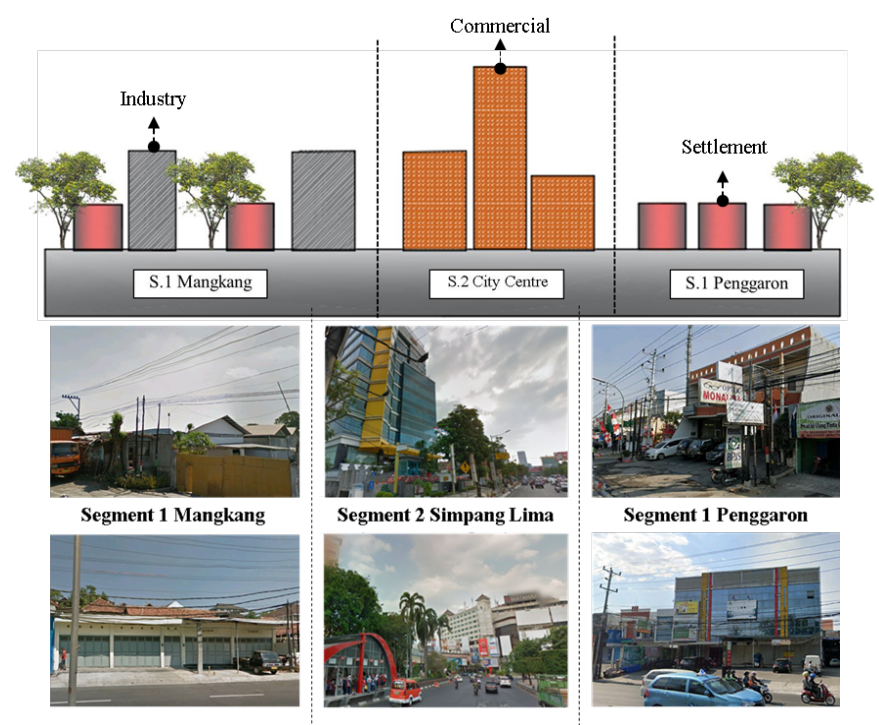

Fig. 10. Pieces of building appearance per segment: cross section of building envelope and google street view.

The relationship between BRT and the urban sprawl phenomena exists as two contiguous currencies, where the existence of BRT is indicated as a trigger for an increase in population and vice versa. It is not impossible for the population to control all forms of public transportation (supply and demand). The overlay result between the population density in Semarang City and the BRT load per corridor shows that the corridors with the highest number of loads in 2018, which are corridors 1 (Mangkang - Penggaron) and 2 (Terboyo Sisemut), has the highest population density in Semarang City. The expansion model that occurs is also in line with the number of linear BRT bus stops which provide the level of building density, distance to the city center, and land prices. In addition, in this study, it was found that the accessibility and price of land were indicated to influence each other to shape the urban distribution caused by the pattern of community activities.

There are two types of urban sprawl that could be formed. The first is the distribution based on the selection of accessibility or access to the road called ribbon development (Thomas et al., 2014), which occurs along corridor 1 at this time. The second is a type of leapfrog that usually occurs due to the selection of cheap land prices, specifically for residential needs. This forms a pattern of building land that is spread far apart or leap of frogs (Akhter and Noon, 2016), as is common in the Southern Semarang region. Of course, it is also undeniable that the urban sprawl in the city of Semarang is caused by the condition of the tides in the low areas of the city, and residents are worried that it could threaten the robustness of the city's buildings and infrastructure. So, geographical and environmental factors are very dominant in influencing people's decisions to move their activities to areas that are consider safe from the tidal flood.

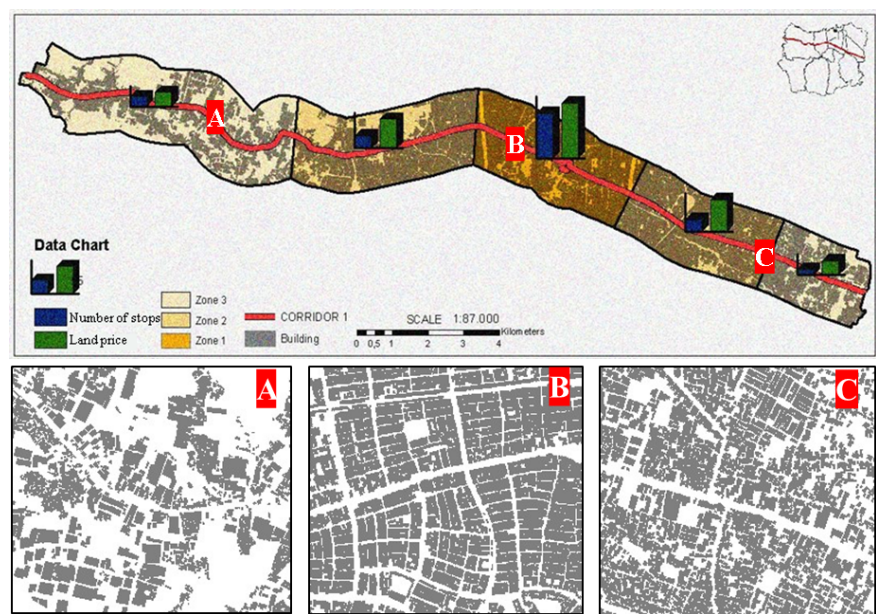

Fig. 11. The spatial appearance of urban sprawl corridor 1: the results of typology data overlay 3 classes (parts), the number of BRT stops, land prices, and buildings, (a) the distribution model of the Penggaron section, (b) the distribution model of the Simpang Lima, (c) the distribution model of the Mangkang section.

Based on the data processing of the number of bus stops, land prices, distance from the city center, and the distribution of buildings, based on Fig. 10 it could be seen that the expansion of land built in the corridor 1 area in Zone 1 (near the center) appears more compact in areas with access to the BRT. This is easily marked by the number of bus stops which totals to 154 units, causing the average land price to increase to 19 Million Rupiah. On the contrary, in Zone 2, buildings are increasingly expanded following the road network, which is indicated because access to the BRT falls short. Here, the number of bus stops decreases to as many as 84 units and land prices tend to fall. In the suburbs located in Zone 3, it is evident that urban sprawl is beginning to occur, as buildings start to expand in distance. In this zone, land prices became much cheaper at around 5 million. The development of sprawl in corridor 1 is strongly influenced by the ribbon development model which depends on easy access to transportation, especially the BRT.

Fig. 11 shows that there are differences in the shape of the buildings expansion of the Mangkang section (a) which is located in zone 3 which has a low building density with a very irregular location that shows quite high sprawl characteristics, while the Simpang Lima (b) section in zone 1 shows the distribution pattern compact buildings with high density and the Penggaron (c) in zone 2 has a fairly regular pattern of building expand with moderate density but still shows sprawl patterns in several parts.

According to Glaeser and Kahn (2004), urban sprawl is an inevitable phenomenon in the development of 21 st-century cities. This phenomenon has a very significant impact, especially for developing countries, where changes in land-use change could massively threaten food security. In addition, settlements could grow irregularly when not equipped with basic facilities such as clean water, sanitation, and electricity. In fact, according to a study conducted by Sudhiraa et al (2004), 
urban sprawl occurring in the United States and India threatens natural resources to be a driving factor for obsession disorders.

The uneven distribution of settlements in the city of Semarang actually caused various impacts such as the water crisis that occurred in several regions, and land subsidence that occurred every year in the northern part of Semarang. Provision of facilities to all regions with a widespread location is certainly a significant challenge for the Semarang City Government, specifically in providing access between regions. Undoubtedly, this would require much higher development costs. The concept of sustainability must always be applied in the current morphological development model of the city, mainly by creating public policies that consider the negative impacts of the urban sprawl phenomenon (Bueno-Suarez and Coq-Huelva, 2020).

\section{CONCLUSION}

The analysis was done to find out the effect of Trans Semarang Corridor 1 BRT data advantage on land prices as well as urban sprawl patterns using spatial analysis methods, descriptive analysis, and also FAR analysis. The obtained results justified the outcome of the allegations in the introduction: the existence of the Trans Semarang Corridor 1 BRT affected changes in land values and also the phenomenon of urban expansion over time caused by land conversion to builtup land. The important findings obtained in this study related to the effect of accessibility with land prices, in general, as there is a mutually influential relationship between accessibility, land value, and the phenomenon of urban sprawl that forms a continuous cycle of living and working in the center of city of Semarang and its surrounding.

a) The results of the spatial analysis of the results of the query between the number of bus stops, land prices, and the distribution of buildings to the distance from the city center which is divided into 3 zones show that in an area that is increasingly away from the city center, the number of available stops will be less and land prices will be cheaper. This also affects the distribution pattern of buildings which has an increasingly tenuous intensity in the periphery, especially the mangkang.

b) Descriptive statistical analysis in measuring the sprawling level shows that the penggaron has a sprawl value of $61 \%$ which is included in the high category. Whereas on the mangkang it has a sprawl value of $32 \%$ which is included in the low category.

c) The height of the building and the density of the building in the segment 1 area of Penggaron and Mangakang with the segment 2 area, which is the downtown area, shows a significant difference. Where the average height in the area of segment 1 reaches 40 meters with high land-use intensity.
While in segment 1 it has an average building height of 10 meters with low land-use intensity. Supporting the previous descriptive analysis, there are differences in building optimization patterns in the Mangkang and Penggaron areas. Where in the Mangkang area is dominated by industrial land use and one-story dwelling with a very tenuous building distance, while in the Penggaron section has land use as trade and services and two-story dwelling with relatively dense spacing between buildings.

The expansion that occurred along corridor 1 formed a ribbon development phenomenon where a land-use changes occurred followed by an easy access to transportation. Similarly, land prices have increased, one of which is due to the proximity of the location of land to the BRT stop. The development of transportation or new transportation networks that aim to increase the ease of mobility of the community turned out to be able to further cause the phenomenon of urban sprawl. The results could be a basis in the process of renewal of development in various cities that should seek to integrate public transportation systems such as the Trans Semarang with land use planning to maintain the sustainability of the city.

Acknowledgments: Many thanks to Prof. Dr. Deden Rukmana as Chairman of the Department of Community and Regional Planning, Albama A \& M University ; and Mohammad Ali Berawi, M.Eng.Sc., $\mathrm{Ph} . \mathrm{D}$, Director of the Directorate of Research and Community Services (DRPM) at the University of Indonesia, Executive Director of Center for Sustainable Infrastructure Development (CSID) FTUI, Chairman of the Infrastructure Task Force in the Indonesia Chamber of Commerce (KADIN Indonesia), who are provided guide and took the time to read the manuscript of this article. This research was financially supported by "Dana Selain APBN DPA Lembaga Penelitian dan Pengabdian Kepada Masyarakat", Diponegoro University, Indonesia through RPI Grand 2019.

Author Contributions: Collecting research data, M.N.F.; the conceptualizing and data analysis, A.R.R.; research methodology and data analysis D.IK.; validation and formal analysis, M.BS.

Conflicts of Interest: The authors declare no conflict of interest.

\section{REFERENCES}

Akther, S. T. \& Noon, M. H. (2016). Modelling Spillover Effects of Leapfrog Development and Urban Sprawl Upon Institutional Deliquencies : A Case for Pakistan. Social and Behavioral Sciences, 216, 279-294.

Alterman, R. (2012). Land use regulations and property values: The quot : Windfalls Capture Idea Revisited. Oxford Handb. Urban Economic Planning, 755-786. 
Augustus, A. (2012). The Influence of Travel Time on Accessibility in Lagos Island. Afrrev Stech, 1, 2, 112-127.

Bandlerova, A. \& Lazikova, J. (2017). Factors affecting the price of agricultural land in Slovakia. Journal of Central European Agriculture, 18, 2, 291-304; doi: 10.5513/JCEA01/18.2.1901.

Black, J.A. \& Conroy, M. (1977). Accessibility Measures and the Social Evaluation of Urban Structure. Environment and Planning, 9A, 1013-103.

Bocarejo, J. P., I. Portilla., M. A. Pérez. (2013). Impact of Transmilenio on density, land use, and land value in Bogotá. Res. Transp. Econ.

Bueno-Suárez, C. \& Coq-Huelva, D. (2020). Sustaining What Is Unsustainable: A Review of Urban Sprawl and Urban SocioEnvironmental Policies in North America and Western Europe. Sustainability, 12, 4445; doi:10.3390/su12114445.

Cervero \& C. D. Kang. (2011). Bus rapid transit impacts on land uses and land values in Seoul, Korea. Transp. Policy, 18, 1, 102-116.

Deng, T., M. Ma. \& Nelson, J. D. (2016). Measuring the impacts of Bus Rapid Transit on residential property values: The Beijing case. Res. Transp. Econ, 60, 54-61.

Drouilles, J., Sophie, L. \& Emmanuel R. (2018). Peri-Urban Residential Neighbourhoods At The Margins Of Current Trends In Urban Growth: Towards Sustainable Transition Paths ? Laboratory Of Architecture And Sustainable Technologies (Last), ecole Polytechnique fédérale de lausanne, Switzerland.

Ewing, R., Pendall, R. \& Chen, D. (2002). Measuring Sprawl and Its Impact Volume I. Washington D.C.: Smart Growth America.

Galster, G., Hanson, R., Ratcliffe, M. R., Wolman, H., Coleman, S., \& Freihage, J. (2001). Wrestling Sprawl to the Ground: Defining and measuring an elusive concept. Housing Policy Debate, $12, \quad 4, \quad 681-717$; doi.org/10.1080/10511482.2001.9521426.

Glaeser, E .L. \& Kahn, M. E. (2004). Chapter 56 - Sprawl and Urban Growth. Handbook of Regional and Urban Economics, 4, 2481-2527; doi: https://doi.org/10.1016/S1574-0080(04)800130 .

Hunter, M. (2012). The Stages of Economic Development from an Opportunity Perspective: Rostow Extended, Geopolitics, History, and International Relations, 4, 2.

Hwang, U. \& Woo, M. (2020). Analysis of Inter-Relationships between Urban Decline and Urban Sprawl in City-Regions of South Korea. Sustainability, 12, 1656; doi:10.3390/su12041656, 2020.

Jain, S., P. Aggarwal., P. Kumar., S. Singhal,. \& P. Sharma. (2014). Identifying public preferences using multicriteria decision making for assessing the shift of urban commuters from private to public transport: A case study of Delhi. Transp. Res. Part F Traffic Psychol. Behavioral, 24, 60-70.
Levinson, D. M. \& E. Istrate. (2012). Access for value: Financing transportation through land value capture. Metrop. Policy Progr. Brookings, 1-21.

Liu, F., Min, M., Zhao, K. \& Hu, W. (2020). Spatial-Temporal Variation in the Impacts of Urban Infrastructure on Housing Prices in Wuhan, China. Sustainability, 12, 1281; doi:10.3390/su12031281.

Lityński, P. \& Hołuj, A. (2020). Urban Sprawl Risk Delimitation: The Concept for Spatial Planning Policy in Poland. Sustainability, 12, 2637; doi:10.3390/su12072637.

Mamcarczyk, M. W., Olczak , B. \& Prus, B. (2020). Urban Features in Rural Landscape: A Case Study of the Municipality of Skawina. Sustainability, 12, 4638. doi:10.3390/su12114638.

McCann, P. (2001). Urban and Regional Economics. Oxford University Press Inc.

Mulley, C. \& C. H. (Patrick) Tsai. (2016). When and how much does new transport infrastructure add to property values? Evidence from the bus rapid transit system in Sydney, Australia. Transp. Policy, 51, 15-23.

Munoz-Raskin, R. (2010). Walking accessibility to bus rapid transit: Does it affect property values? The case of Bogotá, Colombia. Transp. Policy, 17, 2, 72-84

Mustafa, A. \& Teller, J. (2020). Self-Reinforcing Processes Governing Urban Sprawl in Belgium: Evidence over Six Decades. Sustainability, 12, 4097; doi:10.3390/su12104097.

Palei, T. (2015). Assessing The Impact of Infrastructure on Economic Growth and Global Competitiveness. Procedia Economics and Finance, 23, 168-175; doi: 10.1016/S22125671(15)00322-6.

Rakhmatulloh, A. R. I., Buchori., W. Pradoto. \& B. Riyanto. (2018). The Power Of Accessibility To Land Price In Semarang Urban Corridors, Indonesia. J. Malaysian Inst. Planners, 16, 1, 118-129; doi:10.1088/1755-1315/409/1/012021.

Rodríguez, D. A. \& Targa, F. (2004). Value of accessibility to Bogota's bus rapid transit system. A Transnatl. Transdiscipl. J 2004, 24, 587-610.

Sudhiraa, H. S.; Ramachandraa, T. V \&; Jagadish, K. S. (2004). Urban sprawl: metrics, dynamics and modelling using GIS. International Journal of Applied Earth Observation and Geoinformation, $\quad 5, \quad 1, \quad 29-39 ; \quad$ doi: https://doi.org/10.1016/j.jag.2003.08.002.

Thomas ,V., Boussauw, K. \& Pisman, A. (2014). Presence and trends of linear sprawl: Explaining ribbon development in the north of Belgium. Landscape and Urban Planning, 128, 48-59.

Yang, C. H. \& M. F. Yao. (2019). Ultra-High Intensity Redevelopment Of The Core Area Of Japanese Rail Transit Hub Station. International Journal of Sustainable Development and Planning, 14, 3, 245-259. 